\title{
Thinking better about high-quality science: A look at some ethical flaws and productivity evaluation
}

\author{
Eisenlohr, PV. ${ }^{a *}$, Tavares, JR. ${ }^{b}$, Oliveira, SL. ${ }^{b}$, Santos, $A O .^{b}$, Valadão, MBX.. ${ }^{b}$, Bilce, JM. ${ }^{b}$, \\ Roberto, RL. ${ }^{b}$, Castro, HB. ${ }^{b}$, Zaratim, ECP. ${ }^{b}$, Lima, SL. ${ }^{b}$, Santos, AJ. , Silva, APG. ${ }^{b}$, Lima, LB. ${ }^{b}$, \\ Melo-Santos, KS. ${ }^{b}$, Figueiredo, JDS. ${ }^{b}$, Santos, LM. ${ }^{b}$, Pereira, FC. ${ }^{b}$, Oliveira, JCA. ${ }^{b}$, \\ Miguel, TB. ${ }^{b}$, Serpa, AO. ${ }^{b}$, Kreutz, $C .^{b}$ and Reis, SMA. ${ }^{b}$ \\ ${ }^{a}$ Universidade do Estado de Mato Grosso - UNEMAT, Campus Universitário de Alta Floresta, Avenida Perimetral Rogério \\ Silva, s/n, CP 324, CEP 78580-000, Alta Floresta, MT, Brasil \\ bPrograma de Pós-graduação em Ecologia e Conservação, Universidade do Estado de Mato Grosso - UNEMAT, Campus \\ Universitário de Nova Xavantina, BR 158, Km 655, CP 08, CEP 78690-000, Nova Xavantina, MT, Brasil \\ *e-mail: pedrov.eisenlohr@gmail.com
}

Received: October 1, 2013 - Accepted: March 11, 2014 - Distributed: December 31, 2014

Recently, some issues related to scientific ethics and the evaluation of productivity have been increasingly discussed, especially in graduate programs. At the University of the State of Mato Grosso (UNEMAT), on the Campus of Nova Xavantina, Brazil, we have discussed certain issues regarding this subject. We present the main points and perspectives that emerged from this discussion in order to stimulate debate in other graduate programs and shed light on ethical issues that should be addressed to produce high-quality science.

\section{"Salami science", self-citations and cross- citations: origin, definitions and implications}

In ancient times, creativity was guided by the mysteries of nature, and this was reflected in the resulting publications; however, today, creativity is considered an important requirement for a successful career in science (Loehle, 1990). This new conception of both creativity and scientific productivity is accompanied by the fact that the number of published articles, the number of citations received and the impact factor of journals have become essential components for the evaluation of both individual and institutional scientific production.

The pressure to publish can help to explain, but cannot justify, the emergence of some unethical practices, such as 'salami science', 'self-citations' and 'cross-citations'. All of these practices are improper, as they could lead certain authors and journals to be unjustifiably cited. Whereas 'salami science' and 'self-citations' tend to mainly favor the authors, 'cross-citations' are expected to favor journals, at least more directly. All of these practices have been debated worldwide (e.g., Alberts (2013); Koocher and Keith-Spiegel (2010); Misteli (2013)).

'Salami science' can be defined as "[...] slicing of data from a single research process or gathered during a single study period, into different pieces, creating individual manuscripts from each piece, and publishing these to different journals or even the same journal $[\ldots]$ "
(Abraham, 2000, p. 67). This could be a "big deal" for the assessment of graduate programs and researchers because it increases their number of publications, allowing them to gain more prestige and financial support for their research; however, it still poses a serious ethical problem. 'Salami science' should not be confused with articles in a logical series that complement the other articles in the series (e.g., the series on Cerrado woody flora published by Ratter and Dargie, 1992; Ratter et al., 1996; Ratter et al., 2003), or even "smaller" articles that are published by graduate or undergraduate students (Loyola et al., 2012). In our opinion, there is nothing wrong with these two practices and the distinction between them and 'salami science' must be carefully made by the journal editors.

'Self-citation' is "[...] the practice of citing one's previous publications in a new publication [...]" (Gami et al., 2004, p. 1925), whereas 'cross-citation' refers to the situation in which journal ' $\mathrm{X}$ ' cites journal ' $Y$ ' and vice-versa (e.g., Van Noorden (2013)). We believe that both practices present ethical problems only if conducted systematically, because occasionally the available literature is not extensive and authors need to concentrate their citations in a restricted pool of journals. An example of ethically problematic 'cross-citation' is a situation in which there is an agreement among editors from different scientific journals to cite each other to increase their impact factors (Van Noorden, 2013).

'Thomson Reuters', the company that annually calculates and publishes the JCR impact factor, has developed a strategy to punish those who engage in the aforementioned practices. It recently (2013) released an updated calculation of the JCR, and 66 journals that engaged in unethical practices did not appear in the list. Some Brazilian journals were included in this undesirable group and 'earned' themselves a column in Nature (Van Noorden, 2013). The exclusion from the JCR is not an irrevocable decision; as soon as the journals readjust and behave in the manner that is expected of them with respect to ethics and integrity, they will again be included in JCR updates. We do not have sufficient knowledge to judge each of these 66 journals, 
but punishing journals that practice such deception can generally be viewed as increasing the emphasis on valuing ethical behaviors by researchers and journals.

\section{Prospects}

The two important issues underlying our ideas are ethical behavior as an essential component of high-quality science and improvement in the evaluation of researchers and graduate programs. It should be noted that we do not disagree with the current metrics for science quality, but we advocate a more comprehensive evaluation of scientific productivity.

How can a research be productive without compromising the quality, originality and creativity of the work? Finding a balance in this dilemma, to which there is not yet a clear answer, would be the most appropriate manner for assessing the productivity of researchers and institutions. The Brazilian agency CAPES has considered the quality of the science produced (Loyola et al., 2012), but we need further improvements in the methods used to evaluate our science. For example, a basic science study could be evaluated by the impact of the resulting applications. This could result in researchers and graduate programs being evaluated based on the relevance of their studies and their contributions to solving current problems. Moreover, alternative ways of evaluating researchers are now available and should be more encouraged; for example, 'ResearchGate' is a web platform that calculates indices, which are continuously updated, based on various factors, such as the number of articles published, the number of downloads and views of these articles by other researchers, number of citations, and quality of contributions to scientific discussions.

A final suggestion is that governmental agencies create guidelines in which a complete set of recommendations can be addressed, such as an annual limit on self-citations. However, this should be performed very carefully, particularly in Brazil, because too few researchers are working in some scientific areas, and they will obviously engage in selfcitation in an ethical manner. Government agencies and journal editors should distinguish these situations from the other situations discussed here. All of the situations outlined above can aid discussions contributing to the establishment of high-quality peer-reviewed science.

\section{References}

ABRAHAM, P., 2000. Duplicate and salami publications. Journal of Postgraduate Medicine, vol. 46, no. 2, p. 67-69. PMid:11013467

ALBERTS, B., 2013. Impact factor distortions. Science, vol. 340, no. 6134, p. 787. http://dx.doi.org/10.1126/science.1240319. PMid:23687012

GAMI, AS., MONTORI, VM., WILCZYNSKI, NL. and HAYNES, RB., 2004. Author self-citation in the diabetes literature. Canadian Medical Association Journal, vol. 170, no. 13, p. 1925-1927. http:// dx.doi.org/10.1503/cmaj.1031879. PMid:15210641.

KOOCHER, GP. and KEITH-SPIEGEL, P., 2010. Peers nip misconduct in the bud. Nature, vol. 466, no. 7305, p. 438-440. http://dx.doi.org/10.1038/466438a. PMid:20651674

LOEHLE, C., 1990. A guide to increased creativity in research: inspiration or perspiration? Bioscience, vol. 40, no. 2, p. 123-129. http://dx.doi.org/10.2307/1311345

LOYOLA, RD., DINIZ-FILHO, JAF. and BINI, LM., 2012. Obsession with quantity: a view from the south. Trends in Ecology \& Evolution, vol. 27, no. 11, p. 585. http://dx.doi.org/10.1016/j. tree.2012.07.016. PMid:22917847.

MISTELI, T., 2013. Eliminating the impact of impact factor. Journal of Cell Biology, vol. 201, no. 5, p. 651-652. http://dx.doi. org/10.1083/jcb.201304162. PMid:23690180.

RATTER, JA. and DARGIE, TCD., 1992. An analysis of the floristic composition of 26 cerrado areas in Brazil. Edinburgh Journal of Botany, vol. 49, no. 2, p. 235-250. http://dx.doi. org/10.1017/S0960428600001608

RATTER, JA., BRIDGEWATER, S., ATKINSON, R. and RIBEIRO, JF., 1996. Analysis of the floristic composition of the Brazilian cerrado vegetation. II. Comparison of the woody vegetation of 98 areas. Edinburgh Journal of Botany, vol. 53, no. 2, p. 153-180. http://dx.doi.org/10.1017/S0960428600002821

RATTER, JA., BRIDGEWATER, S. and RIBEIRO, JF., 2003. Analysis of the floristic composition of the Brazilian cerrado vegetation III: comparison of the woody vegetation of 376 areas. Edinburgh Journal of Botany, vol. 60, p. 57-109.

VAN NOORDEN, R., 2013. Brazilian citation scheme outed. Nature, vol. 500, p. 510-511. http://dx.doi.org/10.1038/500510a. PMid:23985850. 